\title{
Application of Appropriate Technology in Household Waste Treatment in Community Education Perspective
}

\author{
Elih Mulyana*, I Wayan Ratnata, Wasimudin Surya Saputra, Neris Peri Ardiansyah \\ Department of Electrical Engineering Education \\ Universitas Pendidikan Indonesia \\ Bandung, Indonesia \\ *elih_mulyana@upi.edu, I_wayan_ratnata@yahoo.com,wasimudin@upi.edu, nerisperia@upi.edu
}

\begin{abstract}
This paper aims to describe the educational process of household waste management training by applying appropriate technology as part of human resources development in processing household waste. The participation of housewives and non-governmental organizations in this activity is part of increasing sensitivity to the environment to overcome the problem of household waste. The application of appropriate technology in processing household waste is a major part of the PKM (Community Service) activities of the Assisted Village, the technology of organic and inorganic waste chopping machines is used to produce semi-finished materials for compost and paving blocks, at that stage the technology is appropriate to provide added value in the process household waste treatment. The utilization of organic waste powder that is processed with EM4 produces solid compost, and inorganic waste can be processed as a base material for paving blocks. The results of the PKM in the Assisted Village have added value both in improving the quality of environmental cleanliness and increasing employment for the surrounding community in utilizing appropriate technology as a household waste processor.
\end{abstract}

Keywords-appropriate technology, human resource development, household waste, inorganic waste, organic waste

\section{INTRODUCTION}

Waste management is a problem that is still being sought for the best solution until now. The disposal of garbage that ends up in the TPU creates new problems. Moreover, the increasing population results in an increasing volume of waste, so that new or additional landfills will always be needed if the waste is not managed or recycled to produce something useful. According to data obtained from the State Ministry for the Environment (KNLH) in 2008, the waste produced by Indonesia is 38.5 million tons/year. And 21.2 million tonnes/year produced by Java Island. From the data, it was found that 105 thousand tons of garbage were obtained per day. Then the waste increased to 200 tonnes/day in 2010. In Semarang, around 800 tonnes of waste is dumped at the Jatibarang TPA every day. If not managed, the TPA can reach the maximum limit or overload [1]. Therefore, waste management is crucial, especially in cities.

West Bandung Regency is one of the areas in West Java that faces problems regarding waste management. West Bandung Regency is the result of the division of Bandung Regency. With an area of $1305.77 \mathrm{~km} 2$ and inheriting around $1,400,000$ people from $42.9 \%$ of the old area of Bandung Regency, it is faced with a serious waste problem where data in 2015 from an estimated 645.8 tons of waste generated by residents of West Bandung Regency every day is only around 22, 68 percent or 146.49 tons of waste per day that can be transported by the UPTD (Regional Technical Implementation Unit) for cleaning up West Bandung Regency, plus the waste management served in West Bandung Regency is only in 10 sub-districts, for 40 villages out of a total of 165 villages in West Bandung Regency such as Cipada Village, Kertawangi, Padaasih, Pasirhalang, Pasirlangu, Jambudipa, and others [2].

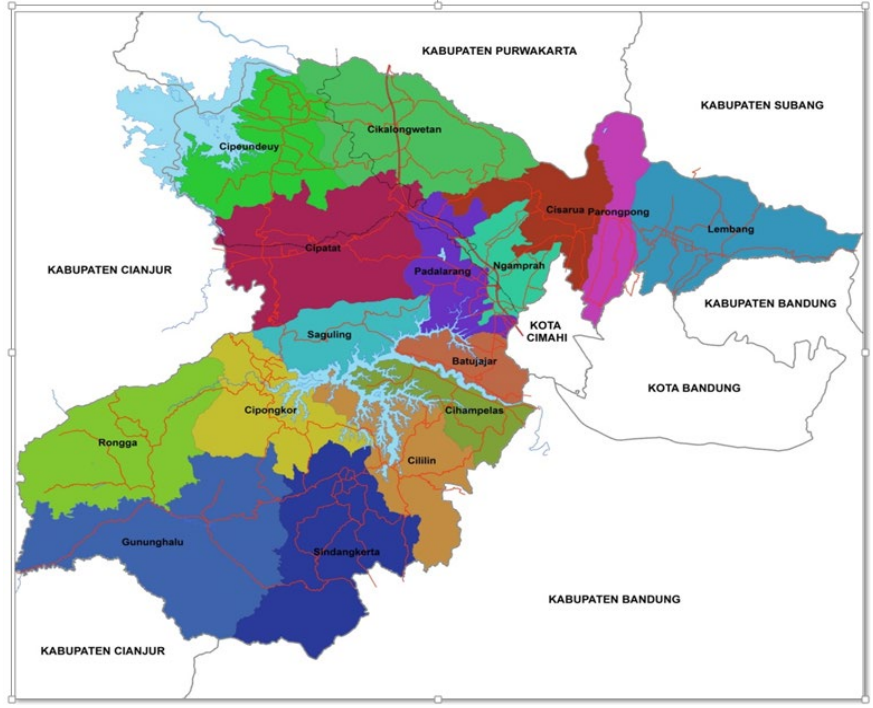

Fig. 1. Location map of West Bandung Regency. 
The village in West Bandung Regency that has not received waste management services is Sukajaya Village in particular. Management of waste in RW 08, seen from the aspect of waste containerization, on average only uses plastic bags for trash bins, while the garbage collection aspect of all garbage is put together without any prior separation, plus there is no temporary disposal of garbage which results in garbage being littered into the river and some were burned. This can cause pollution and will have an impact on the environment later.

In general, farmers who work in Sukajaya Village feel that the price of fertilizers for agriculture is considered quite expensive for plantations and cultivation, with these problems increasing the opportunity where household waste can also be used as fertilizer using appropriate technology by using chopping machine technology and processing it. other development tools to be used in the processing of household waste.

Compost is a fertilizer that comes from the weathering process of materials in the form of leaves, straw, reeds, grass, animal dung, organic waste, and others. Compost has the advantage that it can improve soil physical properties, soil chemical properties, and soil biological properties. This is because the characteristics it has, among others, contain nutrients in varying types and amounts depending on the original material, provide nutrients slowly (slow release) and in limited quantities, and have the main function of improving soil fertility and health $[3,4]$.

The Community Service Program in the Assisted Village has a goal, namely, to increase understanding and awareness in protecting the environment from waste pollution, especially from household waste. The target targets are housewives and non-governmental organizations that do not have skills in household waste management and lack of knowledge about waste management using the technology that has been developed. Organic waste can be used directly, without going through certain processes, for animal feed, especially fish. Organic waste can also be processed for various purposes, including animal feed and compost. To solve the problem of inorganic waste, it can be done to reduce consumption (reduce) reuse (reuse), and recycling (recycle) [5]. Thus, the PKM Assisted Village Program is also provided with assistance and monitoring to see the progress made by the groups that have been created in order to achieve sustainable activities in the community in order to improve environmental cleanliness and obtain benefits economically.

\section{METHODS}

The main subjects in the PKM for the Assisted Village are housewives and non-governmental organizations in Sukajaya Village, West Bandung Regency. This is to facilitate increased awareness of environmental sensitivity and utilize appropriate technology in carrying out household waste management.

In the implementation of activities, the overall activity method is outlined in Fig 1. Thus, the implementation of activities is carried out in a systematic way, while the stages carried out are described as follows (Figure 2):

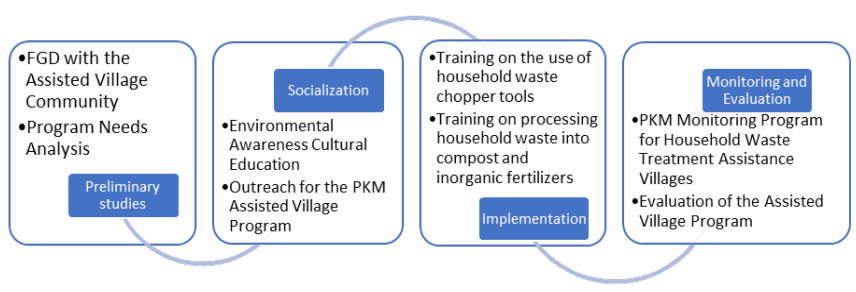

Fig. 2. Methods of PKM assisted villages in 2020.

\section{A. Preliminary Studies}

The Discussion Group Forum is one part of finding out the problems that exist in Sukajaya village related to waste management, which is the main problem in the community, namely the accumulation of waste. Rubbish piling up is caused by the mixing of organic waste which is decaying over time and the presence of inorganic waste that cannot be broken down by the soil. After the FGD was completed, the research team prepared activity materials and activity guidelines for the implementation of the PKM Assisted Village Program related to waste management, at this stage students of the Department of Electrical Engineering Education were involved to take part as a form of Tridarma Perguruan Tinggi. Then a garbage processing simulation was carried out for students at the UPI FPTK Campus to be able to provide a transfer of knowledge and skills at the PKM Assisted Village activities by paying attention to the Goals and Targets of the Assisted Village PKM activities

\section{B. Socialization}

Conducting outreach to the PKM in the Assisted Villages related to counselling on the processing of organic and inorganic waste in the villages of the PKM Program for the Assisted Villages through environmentally conscious cultural activities. In this stage, every citizen is given knowledge and awareness regarding the importance of protecting the environment. This activity collaborates with elements of the community, starting from the village head, RW, RT and NGO heads as well as housewives and community leaders. This is done in order to promote an environmentally conscious culture. Then performed an explanation related to the PKM Assisted Village program plan.

\section{Implementation of Activities}

Strengthening and socializing the activities of the Assisted Village PKM Program to provide insights related to household waste treatment that can be used as economic value for the surrounding community and increase motivation in protecting the environment. Establishment of organic waste processing plant in each house yard per family/family group, distribution of inorganic waste bins per family group. Furthermore, a training of household waste processing skills is carried out using appropriate technology that is applied to be able to make 
waste into processed materials for the manufacture of briquettes and liquid for fertilizers. Image of the sewage treatment process.

\section{Evaluation and Monitoring}

Monitoring of activities by the PKM Desa Binaan team by a team of PKM lecturers to the Assisted Village, to be used as an indicator in evaluating the implementation of PKM-assisted Village activities starting from Input, Process and Output to Training on Appropriate Technology Application in Household Waste Treatment by utilizing Technology Appropriate.

After this activity, the PKM team will continue to communicate with partners about waste management and other problems that become obstacles in the village. The community service location will become a guided village, especially in terms of waste processing. So that communication will continue to be carried out for future program development.

\section{RESULTS AND DISCUSSION}

The results obtained from this activity where the people of Sukajaya Village as part of a development program for the fostered villages showed a change in carrying out household waste disposal. Where all organic and non-organic waste is managed first by sorting it before dumping it into the waste processing house. Starting from their respective homes, the housewives of Sukajaya Village have carried out the process of sorting organic and inorganic waste. This condition is an indicator where there is awareness from the community in protecting the environment, as part of the process of increasing people's understanding of protecting the surrounding environment.

In the process, the stages of household waste management are carried out in stages as shown in Figure 3.

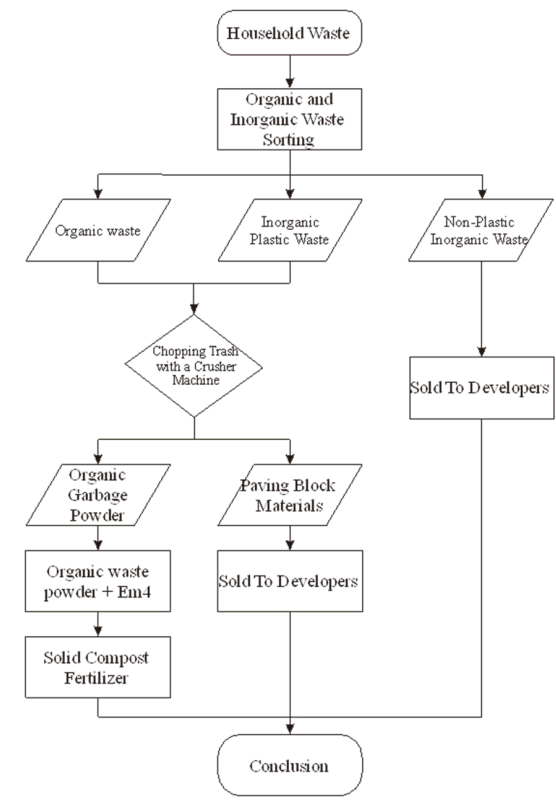

Fig. 3. The flow of household waste processing stages.

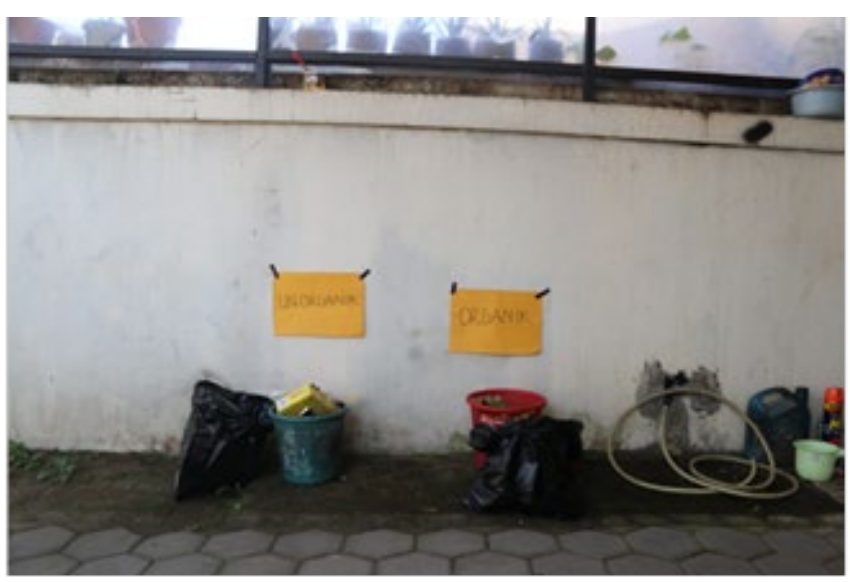

Fig. 4. A place for sorting organic and inorganic waste at home.

In this PKM Assisted Village program where a garbage processing house is built as a place for household waste disposal, this waste processing house is managed by community members who are members of the Sukajaya Village Non-Governmental Organization (NGO) who will later manage waste disposed of by local residents. These waste managers are community members who have participated in the training program during the PKM Program. By providing waste processing skills, both organic and inorganic waste (as Figure 4), waste managers are required to produce recycled waste products that can be used as basic materials for making compost and making paving blocks.

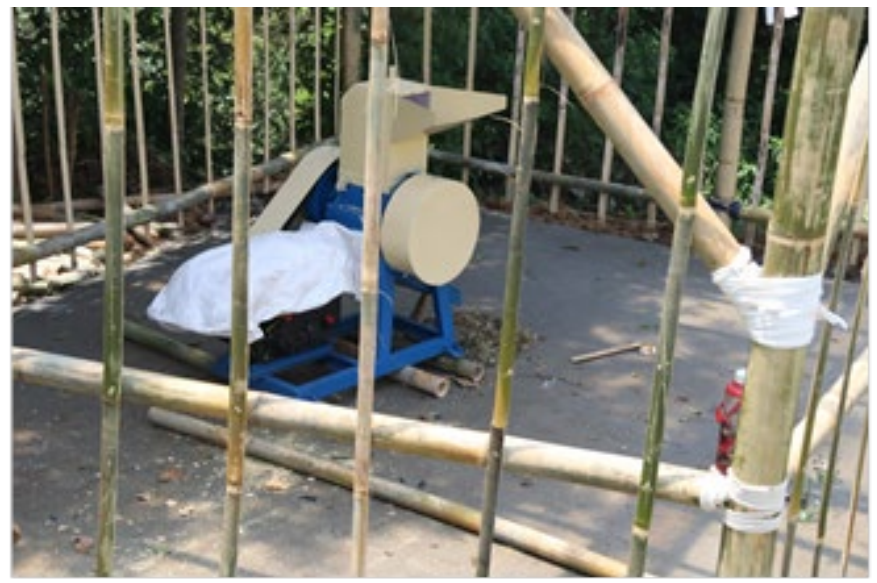

Fig. 5. Place for processing waste.

Household waste that has been separated between organic and inorganic waste is then distributed to the Waste Processing House to be recycled using a chopper machine, organic and inorganic waste chopping is done using a Crusher Machine as a waste processing technology (Figure 5). The recycled output from the machine is treated in order to turn the semi-finished material into finished materials. In its management, each organic and inorganic material is chopped separately, the output of chopping organic waste is used as solid compost. Meanwhile, the chopping product of inorganic waste is used as material for making paving blocks. 


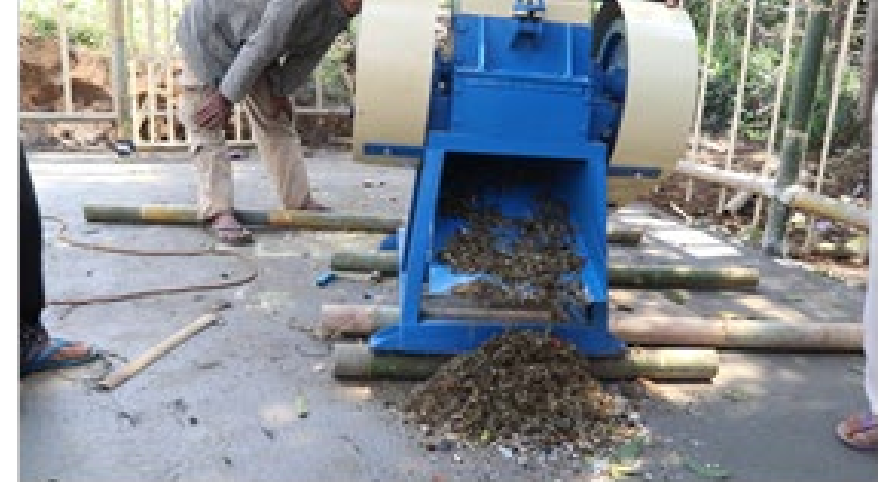

Fig. 6. Chopping organic waste with an efficient machine.

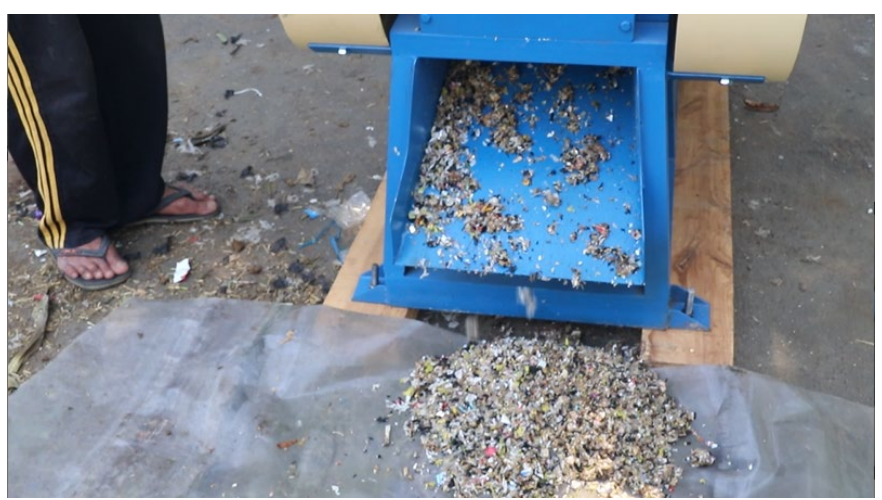

Fig. 7. Chopping inorganic waste with an efficient machine.

In the process of making compost (Figure 6-7), treatment is carried out by mixing the powder from chopping organic waste with EM4 liquid containing microbes by spraying where the composition is $5 \mathrm{ml}$ EM4 with 1 litre of water. Furthermore, a maximum of $40 \mathrm{~cm}$ of organic material is stacked, then covered with gunny sacks, soil, or leaves. In the next stage, temperature control is carried out every 6 hours until the 3rd day, controlling is done so that the temperature does not exceed a temperature of $40 \mathrm{oC}$. After the composting process is complete, compost can be used directly on plants as organic fertilizer [5-7].

In this case, inorganic waste management is carried out in two processes where the first process is that non-plastic waste is separated, such as metal, cans, bottles (glasses), newsprint, and cardboard and then sold so that it can be used by the developer. Whereas those that can be used as paving block materials, such as plastics and similar waste, are chopped using a Crusher machine as an effective technology that turns waste into powder form which can be combined with paving block materials which are then sold to business developers in the field of making paving blocks. With the cooperation between the managers of the PKM PDB program and business developers, it is hoped that any inorganic waste generated by residents can be used as added value in terms of improving the economy of the Sukajaya village waste managers and local residents.
Educational activities that are directly applied to the assisted village community in improving the quality of their abilities, have a role as part of awareness of existing abilities, so that they are able to explore potential and dare to act to improve the quality of life and protect the environment. In terms of the relationship with household waste treatment, from an educational aspect, the transfer of knowledge and skills is an essential part of this training activity. This quality improvement can take place if there is a transfer of knowledge and provision of skills training. The non-formal education model carried out is expected to have a direct impact on society. Judging from the aspect of human resource development, the role of this training education model can improve the quality of human resources in the aspects of knowledge and skills. So that the increase in human resources supported by the use of appropriate technology can be an added value for people who follow this type of training education model.

Thus, the education applied with this training model is expected to have a significant impact on improving human resources. so that society has an increase in carrying out waste management that utilizes appropriate technology.

\section{CONCLUSION}

Based on the results of the implementation of the Application of Appropriate Technology in Household Waste Treatment, the results are:

- There is awareness of residents in protecting the environment by not littering, so that residents have a new culture in carrying out waste disposal by conducting a process of sorting organic and inorganic waste.

- There is a garbage house as a place for processing household waste by using appropriate technology that can recycle organic and inorganic waste which can generate added value for the environment and residents of Sukajaya villages.

- The application of appropriate technology in household waste treatment has a real impact on the cleanliness of the village environment, especially for the residents of RT 01 RW 01. Thus, the application of technology in waste processing coupled with waste processing training is very useful in increasing the community's ability to manage the surrounding waste.

\section{ACKNOWLEDGMENT}

This research is the Fund for the Annual Work Plan and Budget for the Assignment of the Institute for Research and Community Service, Universitas Pendidikan Indonesia for the 2020 Budget. 


\section{REFERENCES}

[1] T. C. Novianty, B. Sudarsono, and S. Subiyanto, "Analisis Geospasial Persebaran TPS dan TPA di Kota Semarang Menggunakan Sistem Informasi Geografis,” J. Geod. Undip, vol. 4, no. 1, pp. 235-243, 2015.

[2] E. Hadyanto, "Tinjauan Teknis Operasional Pengelolaan Sampah Padat Di Pemukiman Warga Rw 17 Desa Jambudipa Kabupaten Bandung Barat," Poltekkes Kemenkes Bandung, 2016.

[3] D. Nurdyanti, A. S. Utami, N. Bastian, and Johan, "Pemanfaatan Limbah Organik Pasar Sebagai Bahan Pupuk Kompos Untuk Penghijauan Di Lingkungan Masyarakat Kota Cirebon," 5Th Urecol Proceeding, no. February, pp. 204-214, 2017.
[4] Y. Djamalu and S. Haluti, "Pemanfaatan Limbah Rumah Tangga Untuk Pembuatan Pupuk Kompos dan Briket,” J. Abdimas Gorontalo, vol. 2, no. 2, pp. 61-65, 2019.

[5] S. Kurnia, W. Hastuti, F. Tentama, S. A. Mulasari, T. Sukesi, and M. Maulana, "Pelatihan pemanfaatan limbah rumah tangga dan limbah pertanian di desa," Semin. Nas. Has. Pengabdi. Kpd. Masy. Univ. Ahmad Dahlan, no. September, pp. 371-378, 2019.

[6] N. Ekawandani, "Efektifitas Kompos Daun Menggunakan Em4 Dan Kotoran Sapi,” vol. 12, no. 2, 2018, doi: 10.31227/osf.io/pyqaj.

[7] Siti Umniyatie, "Pembuatan Pupuk Organik Menggunakan Mikroba Efektif -4(Effektive Microorganism-4)," Pupukorganik, vol. 4, pp. 1-8, 2014. 